\title{
Forum
}

\section{Amphibian conservation: clarifications to comments from Andreone}

\author{
Erin Muthis and Robert N. Fisher
}

W e appreciate the comments from Andreone (2016) regarding our proposed alternative strategy for addressing the amphibian crisis. Andreone recognizes the utility of an Incident Command System approach but doubts the feasibility of implementation at an international level. We stated in our original article, however, that 'the feasibility of our suggestion is debatable, but our point is that radically different approaches are necessary to effectively manage the largest extinction event in modern history' (Muths \& Fisher, 2015). There are examples of where such top-down strategies are being applied; e.g. for the brown tree snake Boiga irregularis (Stanford \& Rodda, 2007), and biosecurity planning for Micronesia and Hawaii (NAVFAC Pacific, 2016). Another example is presented by Andreone. In Madagascar a community-wide conservation plan has been developed complete with prioritization of specific actions (Andreone, 2016). As with any top-down strategy, challenges will surface, especially when making decisions that affect economics. We note this caveat in our article, and Andreone points out such issues in Madagascar, where there are mismatches in priorities between biodiversity conservation and civil needs. Our suggestion is that a new paradigm needs to be considered given the gravity of amphibian decline, and one option may be to take a global approach focusing on specific, major threats. Application of an Incident Command System would not necessitate competition with, or emasculation of, local conservation priorities or actions.

In our article we use the prevention of Batrachochytrium salamandrivorans (Bsal) invasion into North America as 'an example of where an Incident Command System approach could be applied' but not as the only implementation of such an approach. Other amphibian diseases provide equally relevant examples. Recent work in Madagascar identifies another amphibian fungal pathogen (Bd) on the island, coincident with the incursion of the Asian toad, suggesting that immediate actions are warranted (Crottini et al., 2014; Bletz et al., 2015).

ERIN Muths (Corresponding author) U.S. Geological Survey, Fort Collins Science Center, 2150 Centre Ave. Bldg C, Fort Collins, Colorado, USA

E-mail muthse@usgs.gov

Robert N. Fisher U.S. Geological Survey, San Diego Field Station, San Diego, California, USA

Received 13 August 2016. Accepted 14 September 2016. First published online 30 November 2016.
The potential invasion of Bsal into North America is a good example because it is a specific, identified threat that is amenable to a top-down, Incident Command System type of response. This disease received attention from high-level officials from Canada, the USA and Mexico at the Trilateral Committee for Wildlife and Ecosystem Conservation and Management in 2015 and 2016 (Mumme, 2015; Stoett \& Temby, 2015). In contrast to Bsal being a 'USA-centric' issue, it is an example of a continental-scale issue that is being addressed cooperatively by three countries coming together through the Trilateral. This disease, and the potential repercussions to the urodele fauna if it makes its way to North America, has been highlighted as one of the most significant issues affecting North American wildlife (Mumme, 2015; Stoett \& Temby, 2015; U.S. Fish \& Wildlife Service, 2016). Because the significance of this threat was recognized at upper governmental levels, funding was allocated for surveillance monitoring across the USA, starting in 2016, and for a working group to identify key research needs and strategies (Grant et al., 2016). The impact of Bsal extends beyond North America (SabinoPinto et al., 2015). Although the pathogen was identified in Europe, and has already had significant impacts on European urodeles (Martel et al., 2013; Spitzen-van der Sluijs et al., 2013), 47\% of the global urodele diversity is represented in the USA and Mexico (a developing nation). The Trilateral management vehicle is an international mechanism to implement priorities, in this case for a large proportion of urodele diversity.

Overall we find no real contradiction in what Andreone writes. We all seem to recognize the potential of an Incident Command System, or at least a more top-down, approach. Our example from the North American Trilateral and Andreone's description of the efforts in Madagascar illustrate the first steps towards a paradigm shift. As with any shift, it is the implementation rather than the imagining that is the challenge. Andreone draws attention to the dichotomy between what is possible in developed versus developing nations regarding implementation. However, a focus on this dichotomy may be a red herring. In developed countries implementation can be onerous. An example is the level of bureaucracy in the USA or Australia, where actions can be thwarted as a result of many levels of review by multiple agencies, implementation slowed, and management effectiveness reduced (Martin et al., 2012). In contrast, in developing countries a few people with the right resources 
can be effective in implementing actions at relevant time scales (e.g. Gratwicke et al., 2012). Thus, we stand by our suggestion that a shift to an Incident Command System-style effort for amphibian conservation is worthy of consideration.

\section{References}

ANDREONE, F. (2016) Alternative strategies for amphibian conservation: a reply to Muths \& Fisher. Oryx, http://dx.doi.org/10.1017/ So030605316000703.

Bletz, M.C., Rosa, G.M., Andreone, F., Courtois, E.A., Schmeller, D.S., RabibisoA, N.H.C. et al. (2015) Widespread presence of the pathogenic fungus Batrachochytrium dendrobatidis in wild amphibian communities in Madagascar. Scientific Reports, 5 , 1-10.

Crottini, A., Andreone, F., Edmonds, D., Hansen, C.M., Lewis, J.P., Rabemanantsoa, J.C. et al. (2014) A new challenge for amphibian conservation in Madagascar: the invasion of Duttaphrynus melanostictus in Toamasina province. FrogLog, 111, 46-47.

Grant, E.H.C., Muths, E., Katz, R.A., Canessa, S., Adam, M.J., B Allard, J.R. et al. (2016) Salamander Chytrid Fungus (Batrachochytrium salamandrivorans) in the United StatesDeveloping Research, Monitoring, and Management Strategies. U.S. Geological Survey Open File Report 2015-1233. U.S. Geological Survey, Reston, USA.

Gratwicke, B., Crump, P., Baitchman, E., Evans, M., Garelle, D., Hoffmann, C. et al. (2012) Amphibian rescue and conservation project, Panama. FrogLog, 20, 16-2O.

Martel, A., Spitzen-van der Sluijs, A., Blooi, M., Bert, W., Ducatelle, R., Fisher, M.C. et al. (2013) Batrachochytrium salamandrivorans sp. nov. causes chytridiomycosis in amphibians. Proceedings of the National Academy of Sciences of the United States of America, 110, 15325-15329.

Martin, T.G., Nally, S., Burbridge, A.A., Arnall, S., Garnett, S. T., Hayward, M.W. et al. (2012) Acting fast helps avoid extinction. Conservation Letters, 5, 274-280.

Mumme, S. P. (2015) The evolution of natural resource conservation capacity on the U.S.-Mexico border: bilateral and trilateral environmental agreements since La Paz. Review of Policy Research, 32, 19-39.
Muths, E. \& Fisher, R.N. (2015) An alternative framework for responding to the amphibian crisis. Oryx , http://dx.doi.org/10.1017/ So030605315001131.

NavfaC (Naval Facilities Engineering Command) Pacific (2016) Regional biosecurity plan for Micronesia and Hawaii. Http://www.navfac.navy.mil/navfac_worldwide/pacific/about_us/ regional-biosecurity-plan-for-micronesia-and-hawaii-.html [accessed 16 September 2016].

Sabino-Pinto, J., Bletz, M., Hendrix, R., Perl, R.G.B., Martel, A., Pasmans, F. et al. (2015) First detection of the emerging fungal pathogen Batrachochytrium salamandrivorans in Germany. Amphibia-Reptilia, 36, 411-416.

Spitzen-van der Sluijs, A., Spikmans, F., Bosman, W., de Zeeuw, M., van der Meij, T., Goverse, E. et al. (2013) Rapid enigmatic decline drives the fire salamander (Salamandra salamandra) to the edge of extinction in the Netherlands. Amphibia-Reptilia, 34, 233-239.

Stanford, J.W. \& Rodda, G.H. (2007) The brown tree snake rapid response team. In Managing Vertebrate Invasive Species: Proceedings of an International Symposium (eds G.W. Witmer, W.C. Pitt \& K.A. Fagerstone), pp. 175-217. USDA/APHIS/WS, National Wildlife Research Center, Colorado, USA.

Stoetт, P. \& Tемву, O. (2015) Bilateral and trilateral natural resource and biodiversity governance in North America: organizations, networks, and inclusion. Review of Policy Research, $32,1-18$.

U.S. Fish \& Wildlife Service (2016) Injurious wildlife species; listing salamanders due to risk of salamander chytrid fungus. Federal Register, 81, 1534-1556.

\section{Biographical sketches}

ER IN MUThs has studied declining amphibians for $>\mathbf{2 0}$ years, focusing on demography and disease in mountain ecosystems and endangered species. ROBERT FISHer has studied amphibians for 25 years, with work ranging from genetics to invasive species management. Both scientists are involved in the U.S. Geological Survey's Amphibian Research and Monitoring Initiative, where they lead research on amphibians and amphibian decline issues in their regions. 